\title{
Enacting affirmative critique: exploring the conjunctions and overlaps among Actor-network theory and Feminist New Materialist methodologies
}

Emilie Moberg emilie.moberg@buv.su.se

Department of Child and Youth Studies, Stockholm University

\section{Abstract}

This paper elaborates on alternative versions of critique as produced in an ethnographic field work on the everyday life of a curriculum text in a Stockholm preschool. Assisted by Actornetwork theory and Feminist New Materialist methodologies, the paper evolves around three empirical moments where the researcher is depicted as needing to rely on the relational efforts of children, Minecraft figures, concepts, teachers and conversations over coffee. In the paper, Actor network theory and Feminist New Materialist methodologies help to enact alternative versions of critique where dependency and vulnerability is taken as resource. Moreover, a focus on relations and overlaps among entities creates knowledge where for example children and texts are allowed to be strong and vulnerable at the same time.

\section{Introduction}

The limits of critique and the potential alternatives has emerged as a pressing issue in social science research (Braidotti, 2008; Juleskjær and Staunæs, 2016; Gorur, 2017; Latour, 2004; Moats, 2016). Bruno Latour (2004) argues that critique needs to be renewed and suggests social science research to create knowledge on the basis of "matters of concern" instead of "matters of fact". On the issue of metrics in global health, David Moats (2016, p. 1) suggests that anthropologists, for example within the field of Science and technology (STS), need to move from merely presenting critical stories "where governments and private companies proliferate endless numbers". In order to interfere with the excessive "trust in numbers" and quantitative measurement systems, he encourages researchers to share alternative visions of what counts, that is "alternative metrics" (p. 1). Rosi Braidotti (2008), along the same lines, foregrounds an affirmative ethics which "enables the active engagement with the present, by being worthy of it but also by combining it with the ability and the force to resist the negativity" (p 19).

In connection to these discussions on critique in social science research, the present paper will explore alternative versions of critique in relation to an ethnographic study of the everyday life of a 
preschool curriculum text in a Stockholm preschool (Moberg, 2017a, 2017b, 2017c). During different phases of this study, Actor-network theory (ANT) and Feminist New Materialism (FNM) have been actualized and the overlaps and conjunctions between them have become apparent (Latour, 1987; Lenz Taguchi, 2013a). In the present paper, ANT and Feminist New Materialism will be approached as methodologies, specifically indicating the kind of connections that are made among theory and empirical materials. This includes the generation of empirical materials as well as the process of analysing these materials. The concept of methodology is deliberately used in the plural, methodologies, to stress the multiple ways of putting ANT and Feminist New Materialism to work, of which only a few will be mentioned in the present text. With the pursuit of finding more ways of doing critique, rather than abandoning the concept, the paper aims to create knowledge of how Actor-network theory (ANT) and Feminist New Materialist (FNM) methodologies might assist in doing this. The paper will start out with a guide to ANT and FNM methodologies when put alongside one another, with a specific focus on the relations among theory and method including the researcher role. In the next part of the paper I will present three empirical moments generated through an ethnographic study on a preschool curriculum text in a Stockholm preschool, as mentioned above. Examples of what ANT and FNM methodologies offers to the analysis of the three moments will also be presented. The paper will finish off with suggestions of what alternative potentially productive versions of critique that have been created throughout the paper.

\section{Critical approaches in education and early childhood education studies}

Critical approaches are frequently used in social science research in general and education studies more specifically (Moberg, 2017c). To name one example, which connects to the preschool curriculum study introduced above, previous research on curriculum texts and the notion of quality in education practices, including evaluation texts, assessment and documentation, are dominated by critical approaches, drawing on concepts of governmentality, documentality and discourse (Foucault, 1977; Fairclough, 2003). Preschool curriculum texts have for example been approached in terms of tools of regulation and normalization, instrumental tools of assessment and discourses of schoolreadiness, quality control and learning at the expense of care and democracy (Vallberg-Roth, 2014; Dahlberg, Moss and Pence, 2013; Vallberg-Roth and Månsson, 2011; Basford and Bath, 2014). Moreover, previous research on education policy texts in school contexts drawing on ANT also comes to activate a critical approach (Gorur, 2011, 2015; Hamilton, 2017; Koyama, 2012). These studies rely on early ANT accounts of the construction of scientific facts as laid out by Latour and Woolgar (1979) in the book Laboratory Life. In the field of early ANT "laboratory studies" or "practice studies" focus on how (natural) science researchers mobilize papers, machines and researcher colleagues into supporting research agendas and establishing scientific facts. For example, Gorur (2011) draws on early ANT through resembling PISA to a laboratory, where PISA facts are made. While stressing that PISA is a contingent and vulnerable construction dependent on other actors, PISA is above all highlighted as a system regulating and normalizing students through deciding what counts as knowledge. This closely relates to what Gunnarsson in this special issue refers to as "negativity" when it comes to the DISA health manual.

As mentioned above, researchers from different theoretical strands have sought to challenge and extend such an approach (Latour, 2004; Juelskjær and Staunæs, 2016; Braidotti, 2008). In line with 
this, studies in the field of early childhood education attempt to create alternative versions of the concept of quality, which they take to be hijacked by neoliberal and instrumental approaches to quality. In this endeavour, post humanist and FNM methodologies become important methodological resources (Elfström Petterson, 2017; Jones, Osgood, Urban, Holmes and MacLure, 2014; Jones, Rossholt, Anastasiou and Holmes, 2016; Osgood and Guigni, 2015). These studies argue that post humanist ontologies, stressing matter, bodies and becomings, could work to invent new versions of the concept of quality. As part of this, theories and concepts take on a key role in challenging and reinventing the concept of quality in early childhood education. In this sense, FNM methodologies have been used as resources in order to create alternative versions of critique in an early childhood education context. The other methodological approach included in this paper, ANT, has so far never been used to create alternative versions of critique in education research or in early childhood education research. In the present paper, I will argue there is a great potential residing in the empirically driven approach offered by ANT when it comes to create new versions of critique. Also, the methodological sensibility towards relations and mundane objects (Law, 2004; Sayes, 2014) in ANT could prove as an asset in creating alternative versions of critique. In order for this to happen, as will be unfolded in the present paper, ANT is in need of the FNM insights of the researcher as entangled and even produced in the practices $\mathrm{s} /$ he studies. Thus, the paper will explore what kind of resources FNM and ANT methodologies could offer when taken together in suggesting affirmative critical approaches.

\section{Two methodological (overlapping) approaches}

I first came across the overlaps and divergences between ANT and FNM methodologies during the planning phase of the study described above on preschool curriculum texts in a Stockholm preschool. In short, I would say, which will be elaborated on all through this paper, FNM methodologies have provided the research project with a focus on the bodily participation of the researcher as well as the inclusion of children bodies and to some extent teacher bodies in the empirical inquiry. ANT methodologies, on the other hand, have provided the study with a sensibility to the everyday relations among things and people in everyday situations that at first glance could be taken as instances of control and regulation. With ANT methodologies, I have been pushed to thoroughly explore the potential of many things going on at the same time in for example a preschool circle-time event. This insistence on multiplicity in ANT methodologies (Mol, 2002) have generated empirical moments and analysis of how curriculum texts are controlling and vulnerable at the same time, in for example an evaluation meeting (Moberg, 2017c).

ANT is a method and a theory only recently put to work in education studies and early childhood education studies (Gunnarsson, 2015; Heydon, 2012, 2013, 2014; Hultman, 2011; Hamilton, 2015; Koyama, 2015; Moberg, 2017a, 2017b, 2017c; Mulcahy, 2010; Serder, 2015; Verran, 2000). ANT entails a strong ambition to learn from entities in mundane sociomaterial practices (Law, 2004). Importantly, humans and materialities are seen as potentially equally important entities in practices. In ANT, the need to explore the way entities are turned into actors in specific situations through relating to other entities, is emphasized (Latour, 2005). Ethnographic methods, pointing to the ethno methodological roots of ANT (Latour, 2005), are privileged as methods to explore such instances. As a method and theory, ANT specifically highlights the way entities come to act through borrowing and sharing competences among one another (Moberg, 2017a). Along the same lines, FNM 
methodologies stress agency as material and relational. The idea that an object comes to act, or comes into existence (Barad, 2007), only through relations where materialities play an active part is a strong ontological commitment in both ANT and FNM methodologies. However, one strong divergence between ANT and FNM methodologies, which will be elaborated on below, relates to the notion and possibility of practicing reflexivity in social science qualitative research. FNM methodologies entails a strong critique of conventional methods such as interviews, participant observation and ethnography. This is exemplified in the term "post-qualitative", aiming to go beyond conventional methods in order to create other kinds of knowledge (Lather and St. Pierre, 2013). Above all, the conecpt of reflexivity, strongly associated with ethnographic methods, is challenged in FNM methodologies since the researcher is depicted as already enmeshed with what $\mathrm{s} / \mathrm{he}$ studies. Representatives of FNM methodologies, such as Lenz Taguchi (2012, 2013a, 2013b), St. Pierre (2011) and Mazzei (2013) on the other hand, seek to pose the researcher as always already entangled with the world and as produced in the material discursive (Barad, 2007) practices s/he studies. St. Pierre (2011) also problematizes the concept of reflection, presupposing a "stable conscious identity upon which to reflect" (p. 47) and the premises of reflection as a "corrective" guaranteeing the validity of a study. Here I would say one of the divergences between the two approaches lie. While ANT methodologies tend to presuppose a stable researcher role, who is obliged to reflect on his/her research practices, Lenz Taguchi (2013a) questions the assumed "I" of qualitative inquiry using the example of a collaborative research process of which she has been a part (p. 706). Lenz Taguchi (2013a, p. 706) suggests a feminist new materialist ontology, posing intention as emerging in complex networks of human and nonhuman material agents and the researcher as a "collectivebody-assemblage" (p. 714). This means that the researcher and the researched, the knower and the known, becomes impossible to pull apart. In the following quote the bodily process of doing analysis as well as data and researcher(s) as co-produced becomes apparent:

Thus, our individual subjectivities were severely obscured by the multiple foldings and unfoldings of analyses, produced as effects of effects of effects in the process. The further away we got from tracing roots and bundling up lifeworld experiences into neat categories, the closer we got to reading data transcorporeally (Alaimo, 2010) as a fluidity between and through the collective-body-assemblage. (Lenz Taguchi, 2013a, p. 714)

Lenz Taguchi (2013a) in this sense decentres the researcher subjectivity in relation to data and the "material discursive places and spaces where this research was enacted" (p. 715). Moreover, connecting to the theme of researcher subjectivity, Mazzei (2013) refers to herself as a researcher being produced in an interview situation of which she is a part. Mazzei (2013) states: "and while I was the interviewer, I was being produced in the making and doing of the interview. I made agential 'cuts' as an agent but not as an agent in full control of outcomes and becomings" (Mazzei, 2013, p. 737). Ultimately, this points to the researcher as out of control and at the hands of the practices s/he studies. This also hooks onto Guttorms use of a "disruptive poststructural autoethnographic knowledge source" in this special issue, which is, she suggests using Gannon (2006, p. 476), created "from our particular locations in particular bodies with particular feelings, flesh, and thoughts that become possible in particular sociocultural-spatial contexts".

The theme of vulnerability in relation to the researcher role is almost completely absent from ANT methodological research accounts. Some examples exist, however, such as Mike Michael's (2000) analysis of the presence of non-humans, animals and technology in the production of himself as an 
interviewer in a disastrous interview situation. In this interview situation, the informants' cat and pit bull prevents the interview from being recorded. Michael 's (2000) account includes his own fear of the pit bull terrier as well as his insecurity in the interview situation. In ANT methodologies overall, though, vulnerability is downplayed while reflexivity is a key methodological issue in relation to empirical inquiry. Here, the issue of reflexivity is closely related to the question of transparency as to what kind of methodologies are applied in an inquiry (Woolgar, 2000; Law, 2004; Mol, 2002). Law (2004) for example, stresses the researcher as complicit in creating the practices $\mathrm{s} / \mathrm{he}$ studies and calls researchers to reflexively attend to the methods and tools whereby they "craft realities" (Law, 2004).

Another important parameter when presenting ANT methodologies and the connections between theory and empirical materials, is the role of structures and discourses as explanatory tools. Callon and Latour (1981), for example, questions the way society comes to be overused in sociology research as an overarching explanation of certain phenomena. In granting societal structures explanatory powers, Callon and Latour (1981) argue that sociologists help making society into a macro actor, or, as they put it: sociologists help "macro-actors structure reality" (Callon and Latour, 1981, p. 262). For example, Callon and Latour (1981) write:

Too often sociologists - just like politicians or the man in the street - change their framework of analyses depending on whether they are tackling a macro-actor or a microactor, the Leviathan or a social interaction, the culture or individual roles. By changing the framework of analysis while this is under way, they confirm the power relations, giving aid to the winner and giving the losers the 'vae victis'. (Callon and Latour, 1981, p. 280)

This quote indirectly refers to the focus on empirical situations in ANT methodologies as well as the close attention to technical details and mundane objects. This quote also closely relates to the difficulty that I experienced when working with ANT methodologies in a preschool setting, namely the difficulty or even impossibility of defining a tool or a text as a macro or a micro actor. In an empirical inquiry, with ANT, these distinctions become impossible to uphold. Instead, ANT methodologies, I argue, seek to generate analysis in which the status of being a so called "macro" actor can only be achieved through relying on the hard work of so called "micro" actors. This commitment in ANT methodologies takes active part in creating alternative versions of critique, which will be elaborated on the final part of the paper.

Another important divergence between ANT and FNM methodologies relates to the role of theoretical concepts. In FNM methodologies theoretical concepts become emancipatory and potentially productive of new realities, which could be exemplified by the above stated attempts to invent new version of the concept of quality (Jones, Osgood, Urban, Holmes and MacLure, 2014; Jones, Rossholt, Anastasiou and Holmes, 2016; Osgood and Guigni, 2015). ANT methodologies, on the other hand, especially the so called "post-ANT" approach, could be seen to offer methodological sensibilities rather than a 'strong theory' (Gad and Bruun Jensen, 2009; Law, 2004; Sayes, 2014). The issue of what constitutes a strong theory or not is, in my view, difficult to settle when it comes to ANT. As noted above, ANT methodologies entail strong methodological principles, such as the principle of general symmetry. These methodological principles are in some sense impossible to separate from what could be termed as theoretical principles. At the same time, the use of empirical situations as starting points of inquiries and the commitment to long-term field work is an important 
feature of ANT methodologies. For example, Latour $(1988,2005)$ notes that the ANT-ethnographer should be aware of letting theoretical concepts too easily capture the doings of local actors. The ANT analyst needs to, he suggests, carefully acknowledge the analyses and concepts already circulating in practices. However, while ANT encourages the researcher to constantly stay alert to the ambivalence, multiplicities and shifts at play in practices, the same attention has not been directed at the ambivalence, multiplicities and shifts at play in producing the researcher. The overlaps and divergences between ANT and FNM methodologies, as described above, will now be elaborated on in relation to the ethnographic fieldwork, foremost participant observations, that I conducted as part of the study of a preschool curriculum text referred to above.

\section{Three moments in an ethnographic fieldwork}

In this section I have chosen to specifically focus on three empirical moments as they offer, I argue, specific challenges when striving to create alternative versions of critique. The participant observations were carried out in a Stockholm preschool and entailed the researcher spending approximately two full days a week in an extended preschool space playing, sitting on carpets, singing, eating, writing field notes in the little black notebook, going to theatre visits and going to parks. All together I spent approximately 10 months in the preschool with 16 children aged four and five and their three teachers. I will use the term participant observations to describe the time I spent in the preschool as a researcher. I am aware that the concept of observation evokes an idea of distance in ethnographic work, which the present paper does not adhere to. However, in line with the affirmative approach outlined in the present paper, I wish to add to and expand the term participant observation rather than to dismiss it (Moberg, 2017c). The first of these empirical moments, on laminated notes, children and a researcher, has also been included and analysed in Moberg (2017a).

\section{Laminated notes, children and a researcher}

One morning I am sitting next to the children in a circle on the green carpet. One of the children next to me sits very close, leaning towards me. One of the teachers has brought the big laminated pictures of different places within the preschool space. The photos depict the forest, the preschool playground, the art room, the library and the indoor rooms. The teacher also brings the box containing small laminated notes with all the names of children and teachers on them. We start clapping on our knees, singing in Swedish: Jag säger godmorgon till dig, klapp, klapp, klapp, jag säger godmorgon till dig, klapp, klapp, klapp, jag säger godmorgon, jag säger godmorgon, jag säger godmorgon till dig, klapp, klapp, klapp. As soon as the teacher places the pictures of the five places in the preschool area on the carpet in front of the children, some children exclaim: 'Oh, I really hope I get to be inside'. Another one shouts: 'I don't want to go outside!' Someone else says: 'I want to be in the art room!' The teacher refers to the schedule above the sink in the same room saying the art room is not theirs until next week.

One child is particularly persistent and manages to voice over the other children and teachers: ' don't want to go outside!' A few seconds later I notice the teacher is placing the note marked with the child's name on the picture of the preschool outdoor playground. 'Oh, no, I refuse', the child exclaims. The activity of placing children's names in each of the five pictures goes on. Some children get their name placed on the picture of the forest, some get their name placed on the picture of the inside rooms and some get their names placed on the picture of the outside preschool playground. I 
look away for a few seconds and when I look back at the picture of the outdoor playground the note with the name of the child refusing to go outside is gone. I look around and see the child standing by the window, a few meters away from the carpet, fiddling around in the box with Playmobile figures, picking up one figure and lifts it up in the air. I see the laminated note clasped in one of his/her hands. I instinctively smile, get up from my place in the circle and start writing in my notebook.

None of the teachers notice that the child has got the note in his/her hand and I don't tell them. The child by the window with the note in his/her hand sees that I am writing. The child comes up to me and asks if $s /$ he can put the laminated note with the name on it between the pages of my notebook. 'Why', I ask. 'Because I don't want to go outside', s/he answers. I don't know really know what to do. I say something mumbling and hope $s /$ he will think I'm boring and refrain from asking any more favours of me. A teacher comes in and says: 'We need to go out now'. 'But I want to be inside', the child says. The teacher quickly glances at the schedule put up on the space above the sink.

'Tomorrow your group is going to be inside before lunch', she says after consulting the schedule. As I later go out into the playground I must ask the child where s/he put his/her note. 'Well, I put it in the box where it is supposed to be', the child responds.

This moment could potentially be analysed as a moment where children become normalized and directed into specific kinds of discursively loaded preschool events, such as the activity of going outside. In the end, the teacher, the laminated nametag, the carpet and me as a researcher all act to make sure that the child goes outside. This would be in line with a critical analysis of the regulative preschool institution where children are fostered into what are considered to be 'good' activities. However, joint ANT and FNM methodologies offer other and more ways of analysing the moment, which makes a huge difference to what becomes of the child, the nametag, the teacher and the researcher. This actualizes the example set forth by Hohti in this special issue about the relational agency of a paper form. With ANT, the laminated nametag could not be simply analysed as a regulative tool meant to organize children into activities. Rather, when thinking with the principle of general symmetry in ANT, the laminated nametag comes to offer the child capacities and incentives to get up from the carpet and leave the circle time position. In this sense, neither the teacher, the child, the name tag or the carpet are assumed to carry any specific regulative qualities prior to their relations to one another. In a way, the child also makes use of me and my note book to further prolong his/her time inside, to somehow postpose the activity of going outside. This points to the commitment in FNM methodologies of posing the researcher as mixed up in the practices s/he studies, making it hard to really say who studies who and what kind of knowledge is created. This commitment in FNM methodologies makes it impossible for me as a researcher to hide behind notions of reflexivity, which would require a stable researcher "I" reflecting on a research practice (St. Pierre, 2011). Instead, I have become encouraged to display what a researcher body feels, experiences and does. For example, what does it bodily entail to attend a circle time event three times a day as a researcher, that is to be seated on a carpet with limited space when you are a tall person, as I am (Moberg, 2017a). These bodily possibilities and limitations as a researcher has consequences to the research methodology; when I was sitting down on small chairs or carpets, I was inclined to sit there for a while since it was too hard getting up. This slowed down my participation in the everyday preschool work and made me less motivated to move around among many different sites during a day. 


\section{Children, Minecraft figures and a researcher}

Another moment in my field work is closely related to this. One afternoon in the preschool I sit close to a child in a hard sofa in the combined reading and Lego building room. I read a Minecraft manual out loud and the child fills in on the details I lack knowledge of. I am pushed to devote all my thinking energies towards following the Minecraft figures in the manual. I register their names, their abilities, their superpowers, which one is friendly and which one is not so friendly, what tools they possess and the different places that the game could take you. There is an endless stream of details, colours, numbers, materials, letters, pictures and maps. During my fieldwork, many of these moments and locations were played out. Somehow, I managed to keep update with some of the figures. I was encouraged by the look, both surprised and happy, as the children found out I was actually listening and absorbing (some of) the Minecraft manuals and figures. This ability of mine to listen and absorb was sharpened and supported by the Minecraft figures and children's engagements. This points to children and Minecraft figures as actors that the researcher needs to rely on and share qualities with in order to carry out research (Mol, 2002, 2010). Furthermore, the frequency and engagement that children and Minecraft figures draw me into their relations expands my ability to sense and listen. The Minecraft figures, even though not formally allowed in the preschool indoor space, somehow manage to get into children's games and the researcher notebook. Sometimes, though, they are directed to the personal boxes that each child has in the preschool, where they keep personal belongings, drawings, cuddly toys, clothes and Minecraft books and figures.

A potential critical story could be created out of these moments that centres around the potential destructive forces, or at least time-consuming qualities, of popular culture in relation to the issue of children as consumers. With joint ANT and FNM methodologies as resource, something else happens, however. Holding onto Lenz Taguchi's (2013a, p. 706) concept of a "collective-bodyassemblage" the knowledge that is generated in and through this moment arises as bodies are sitting close to one another at the same time as material objects and passions become shared. It is impossible for me to create distance enough to the event in order to problematize children as consumers or the fact that the Minecraft figures seem to get into the preschool space even though they are formally banned from there. This implies a kind of critique where closeness to the research practice becomes a resource rather than something for the researcher to reflect upon, as a "corrective" safeguarding the validity of a study (St. Pierre, 2011, p. 47). Here, the FNM commitment of foregrounding the researcher vulnerability and bodily closeness, becomes an important resource when analysing the moment. Furthermore, ANT methodologies direct my attention to the specific relations and connections among entities in these empirical moments. This creates possibilities of making an analysis where the child, the Minecraft manual and myself as a researcher constantly overlap and depend on each other in order to act. This move, in its turn, makes it hard to identify any kind of one-sided control or regulation being played out in the empirical moments.

R.

The last empirical moment I wish to engage with concerns the practice of writing your name in a preschool/school. One day two teachers from one of the nearby schools come to visit the preschool. Eight of the six-year old children in the preschool group that I am taking part in are starting at that specific school next term. The teachers ask the children to make drawings connected to something they like to do. The teachers explain to the children that they mean to take the drawings with them to the school and put them up on the wall. In this way, the drawings are there to welcome the 
children as they start next term. The children are thus encouraged to write their name, if they can, on the drawings, "so that you can see when you come to school, that is my drawing", the teachers say. The children come to be divided among two tables. At one of the tables all children draw Minecraft related things. The Minecraft figures have no fingers, one child says. But how do they manage to lift things, one teacher asks. They do it like this, one child says and clenches his/her fists and raise them up in the air as if $s /$ he lifts something. $S /$ he draws a Minecraft figure without fingers. "But what is it supposed to lift", someone asks. "A fishing rod", the child says. One child has written R. (dot) on his/her drawing. "Could you write your whole name", the teacher asks? "No, I don't want to", the child says. "You can try", the teacher says. "How do you usually do here", the teacher asks one of the preschool teachers. "Do you want us to fetch a name tag somewhere with your name on it", the preschool teachers ask the child. "Yes, I want to fetch the one on my box", the child says. The preschool teacher fetches the laminated nametag from the box and $R$ writes the rest of his/her letters down.

Later, in the coffee room, the preschool teachers react to the way the teachers demanded the child to write his/her name. "Why is that so important?" Especially the story about R becomes circulated in the staff room, different teachers filling in on each other's stories as they were allowed different knowledge on the story from their seating in different parts of the room. I tell my part of the story, which is played out after the teacher visit is over. $\mathrm{R}$ sits on the rectangular carpet in the "building area" making a ball out of magnets. $\mathrm{S} /$ he lifts it up in the air, as if it is flying. $\mathrm{S} /$ he places a small bear inside the ball and lifts it again. "This is my bear and it is supposed to fly", $s /$ he says. "Ah", I say. "R, can I ask you something?" I say. "Yes", s/he answers. "Did you write your name on the drawing when the teachers were here?". "No, I didn't' want to", s/he says. "Ok", I say. S/he keeps on playing with the bear in the magnet ball. "But I still wrote my name later", s/he says. "Ah, ok", I say. "I went to fetch my name tag on my box and then I looked at it and wrote my name". "But do you know what', s/he says and laughs. "No", I say. "I forgot to put it back on the box again". "Oh?", I say. S/he laughs again. "But now I put it back again, after we had been outside in the playground". It is circle time and the child puts the bear, which s/he brought from home, in his/her box.

In the coffee break, I find myself highly engaged in telling my part of the story, taking part in creating a "whole" story of the child who decides to write: R. This story could potentially be told as a story of the discourse of 'school preparation', which already before children start school draws them into a testing culture. This story could make use of the drawings and the assignment to write your name in the teacher visit as a concealed test of individual skills. This potentially critical story did not appear to me until revisiting this situation when writing this paper. Until then I was fascinated by the writing of the dot and the way the dot and the child took part in producing ambivalence among teachers and paused the whole event of writing your name. In the end, what seemed to amuse the child the most was that $s /$ he had forgotten to put the nametag back. For what is a personal box without a nametag? When working with both ANT and FNM methodologies in relation to this moment there are many potential actors; the dot, the paper, the child, Minecraft figures, the name tag and the box. Directing attention towards the relations among actors accomplishing events creates an alternative version of critique. This alternative version does not aim at uncovering hidden structures or, as $\mathrm{Mol}(2002, \mathrm{p}$. 158) notes, "living up to reality". Rather, this alternative version of critique creates knowledge, again with Mol's words, "by finding worthwhile ways of living with the real" (Mol, 2002, p. 158). In this sense, the ethnographic work I carried out in the preschool, not necessarily the duration of time or 
the number of hours, but the affects, engagements and intensities that you become part of as a researcher, does something to produce alternative versions of critique.

\section{Concluding discussion: adding more versions of critique}

While ANT methodologies have afforded the analysis of the above described moment with possibilities of featuring relations and potential symmetries among entities, FNM methodologies have, in line with the above analysis of the circle time moment, actualized the researcher body as enmeshed with the practices s/he studies. By admitting and giving in to the engagements and affects that for example the dot or the Minecraft manual generates, the researcher is afforded with possibilities of creating other kinds of knowledge when compared to a critical approach. A critical approach, I argue, risks privileging structure and order at the expense of ambivalence and multiplicity. This risk responds to Callon and Latour's (1981) critique of sociology scholars giving too much explanatory power to society and structures. Along these lines, a critical approach, potentially works to further support and stabilize structures and discourses instead of interfering with their potentially controlling or regulative powers over children or teachers. A joint ANT and FNM methodological approach is, on the other hand, an approach which privileges ambivalence and multiplicity over structure and order (Moberg, 2017a). This closely connects to Andersen in this special issue, as she refers to critique as a way to "multiply and vitalize strange happenings to push problematic repetitive reality-creating forces in new directions".

Thus, this paper has sought to explore what potential alternative to critique could be created when using ANT and FNM methodologies as joint resources. With ANT methodologies, as has been displayed throughout the paper, the researcher needs to think of Minecraft figures, texts, schedules and children as potentially equally influential in empirical situations. This undermines a critical approach and creates alternative versions of critique. Similarly, FNM methodologies have provided invaluable input in challenging the notion of a stable researcher "I" (St Pierre, 2011). In that sense, FNM methodologies have constantly acted to remind me that, as Lenz Taguchi (2013a) notes, the researcher crucially depends on the "material discursive places and spaces where the research was enacted" (p. 715). This closely relates to Mazzei's (2013) analysis of the researcher being produced in an interview situation along with Michaels (2000) description of the interviewing researcher as dependant on a pit bull, a cat and a (functioning) tape recorder. In the above described everyday empirical moments, where the researcher (sometimes involuntarily) shares frustrations and joys with children, carpets, Minecraft manuals and teachers, it becomes obvious that both theory and researcher falls short in providing solutions or obtain "clearer" descriptions of what is actually going on in practices. In this sense, which both ANT and FNM methodologies have encouraged, I am inclined to abandon the kind of critique that allows the researcher to know more of their reality than the practitioners themselves do (Latour, 1988). This echoes St. Pierre's (2011) critique of the researcher as "the enlightened, privileged saviour who can recognize and act on injustice when they see it" (St. Pierre, 2011, p. 43). Moreover, it connects to Latour's (1988) argument on the limits of the researcher's powerful gaze. Both St. Pierre (2011) and Latour (1988) thus interferes with a division between theory and practice, in which theory is positioned as a powerful tool to identify oppressive structures (Latour, 1988). This closely connects to my bodily experiences of doing ethnographic work in a preschool. As I have become drawn into the everyday frustrations and joys of 
preschool practitioners and children, I have become the one who has limited theoretical-practical knowledge of the preschool reality.

Returning to the overview of critical approaches in education research and early childhood education research mentioned early on in the paper, the alternative versions of critique suggested in the present paper hook onto, add to and shift these critical approaches. Critical approaches, with Foucault (2008) or Fairclough (2003) should not be abandoned, however, they need to be complemented with more versions of critique. Such an expanded approach, as suggested in the present paper, could potentially generate empirical moments and analysis of how for example curriculum texts are controlling and vulnerable at the same time. Moreover, again using the example of curriculum texts, such an expanded approach might produce knowledge of the way children and materialities do much more with curriculum texts and preschool settings than what might appear with a critical approach (Moberg, 2017a).

Thus, my readings of and engagement with ANT and FNM methodologies, as discussed above, has encouraged me to admit, even use and exploit, my dependence, my frustrations and my feelings of being inadequate and superfluous in the everyday preschool work. Furthermore, I have been encouraged to give up on finding answers to questions of how to properly reflect on my research practice. Consequently, when starting from my dependence to the practices I set out to study I have become allowed to explore what the mutual relations among researcher, materialities, humans and ideas activated in the research practice could become productive of. As has been displayed throughout the paper, this closeness, through moments and locations in the ethnographic work, construct and assemble overlaps, dependencies and affects among researcher, children, texts and things. These relations, I argue, act to produce alternative versions of critique. Along these lines, the strongest experiences from my fieldwork and the participant observations is how I constantly have become seduced, convinced, instructed, betrayed and lured, but also supported, backed and encouraged by empirical moments, children, teachers, texts, concepts and things like carpets and Minecraft manuals.

\section{References}

Barad, K. (2007). Meeting the Universe Halfway, Duke University Press. https://doi.org/10.1215/9780822388128

Basford, J. \& Blath, C. (2014). Playing the assessment game; an English early childhood education perspective. Early Years. 34(2), 119-132. https://doi.org/10.1080/09575146.2014.903386

Braidotti, R. (2008). Affirmation, pain and empowerment, Asian Journal of Women's studies, 14 (3), 7-36. https://doi.org/10.1080/12259276.2008.11666049

Braidotti, R. (2012). Nomadic theory - The portable Rosi Braidotti. Colombia University Press.

Callon, M. (1986). Some elements of sociology of translation: Domestication of the scallops and the fisherman of St. Brieuc Bay. In: Law, J. (eds.), Power, action, belief. A new sociology of knowledge, 196-229, Routledge and Kegan Paul, London.

Callon, M. and Latour, B. (1981). Unscrewing the Big Leviathan: how actors macro-structure reality and how sociologists help them to do so. In Knorr-Cetina, K. and Cicourel, A. (eds.) Advances in Social Theory and Methodology: Towards an Integration of Micro and Macrosociologies, 277-303. Routledge and Kegan Paul, Boston.

Dahlberg, G., Moss, P. and Pence, A. (2013). Beyond Quality in Early Childhood Education and Care. Routledge, New York. 
Elfström Petterson, K. (2017). Production and products of preschool documentation: Entanglements of children, things and templates. Phd diss, Linköping university.

Fairclough, N. (2003). Analysing discourse: textual analysis for social research. Routledge, New York.

Foucault, M. (2008). Diskursernas kamp. Eslöv: Brutus Östlings bokförlag Symposion.

Gad, C. \& Jensen, C. Bruun (2009). On the Consequences of Post- ANT. Science, Technology \& Human Values $35,55-80$.

Gannon, S. (2006). The (im)possibilities of writing the self-writing: French poststructural theory and autoethnography. Cultural Studies $<=>$ Critical Methodologies 6 (4), 474-495. https://doi.org/10.1177/1532708605285734

Gorur, R. (2011). ANT on the PISA Trail: Following the statistical pursuit of certainty. Educational Philosophy and Theory. 43(1), 76-93. https://doi.org/10.1111/j.1469-5812.2009.00612.x

Gorur, R. (2015). Producing calculable worlds: education at a glance, Discourse: Studies in the Cultural Politics of Education, 36:4, 578-595. https://doi.org/10.1080/01596306.2015.974942

Gorur, R. (2017). Towards productive critique of large-scale comparisons in education. Critical Studies in Education. https://doi.org/10.1080/17508487.2017.1327876

Gunnarsson, K. (2015). Med önskan om kontroll - figurationer av hälsa i skolors älsofrämjande arbete. Phd Diss. Stockholms universitet.

Hamilton, M. E. (2017). How International Large-scale Skills Assessments engage with national actors mobilizing networks through policy, media and public knowledge, Critical Studies in Education. https://doi.org/10.1080/17508487.2017.1330761

Hamilton, M., Maddox, D. \& Addey, M. (2015). Literacy as numbers: researching the politics and practices of international literacy assessments. Cambridge University Press.

Heydon, R. (2013). Learning opportunities: The production and practice of kindergarden Literacy curricula in an era of change. Journal of Curriulum Studies. 45(4), 481-510.

Heydon, R., Crocker, W. \& Zhang, Z. (2014). Novels, nests and other provocations: Emergent Literacy curriculum production in a childcare centre. Journal of Curriculum Studies. 46(1), 1-32. https://doi.org/10.1080/00220272.2013.803158

Heydon, R., Moffatt, L., \& Iannacci, L. (2015). 'Every day he has a dream to tell': classroom Literacy curriculum in a full-day kindergarten. Journal of Curriculum Studies, 47(2), 171-202. https://doi.org/10.1080/00220272.2014.1000381

Hultman, K. (2011). Linjaler, barn och andra aktörer - posthumanistiska perspektiv på subjektskapande och materialitet i skola/förskola. Phd. Diss. Stockholms universitet.

Jones, L. Osgood, J. Urban, M., Holmes, R. \& MacLure, M. (2014). Eur(ope): (Re)assembling, (re)casting and (re)aligning lines of de- and re-territorialisation of early childhood. International Review of Qualitative Research. Spring, 7 (1), 58-79. https://doi.org/10.1525/irar.2014.7.1.58

Jones, L. Rossholt, N., Anastasiou, T., Holmes, R. (2016). Masticating quality and spitting the bits out. Contemporary Issues in Early Childhood. 17(1), 26-38. https://doi.org/10.1177/1463949115627897

Juelskjær, M. and Staunæs, D. (2016) Designing leadership chairs: experiments with affirmative critique of leadership and environmentality. Reconceptualizing Educational Research Methodology. 7(2), 35-51. https://doi.org/10.7577/rerm.1840

Koyama, J. P. (2012). Making Failure Matter: Enacting No Child Left Behind's Standards, Accountabilities, and Classifications. Educational policy, 26(6), 870-891. https://doi.org/10.1177/0895904811417592

Koyama, Jill. (2015). When Things Come Undone: The Promise of Dissembling Education Policy. Discourse: Studies in the Cultural Politics of Education, 36(4),1-12. https://doi.org/10.1080/01596306.2015.977012

Lather, P. A. \& St. Pierre, E.A. (2013). Post qualitative research. International Journal of Qualitative Studies in Education, 26(6), 629-633. https://doi.org/10.1080/09518398.2013.788752

Latour, B. (1986). The powers of associations. In: Law, J (eds.) Power, Action and Belief. A New 
Sociology of Knowledge? 264-280, Routledge \& Kegan Paul, London.

Latour, B. (1987). Science In Action: How to Follow Scientists and Engineers Through Society, Harvard University Press, Cambridge Mass.

Latour, B. (1988). The politics of explanation: an alternative. In Woolgar, S. (eds.) Knowledge and Reflexivity, New Frontiers in the Sociology of Knowledge, 155-177. Sage, London.

Latour, B. (1991). Technology is Society made durable. In: Law, J. (eds.) A Sociology of Monsters Essays on Power, Technology and Domination, 103-132. Routledge \& Kegan Paul, London.

Latour, B. (1999). On recalling ANT. In Law, J \& Hassard, J. (eds.) Actor Network Theory and After, 1525, Blackwell Publishers, Oxford. https://doi.org/10.1111/i.1467-954X.1999.tb03480.x

Latour, B. (2004). Why has critique has run out of steam? From matters of fact to matters of concern. Critical inquiry. 30, 1-24. https://doi.org/10.1086/421123

Latour, B. (2005). Reassembling the social: An introduction to Actor-Network-Theory. Oxford University Press, Oxford.

Latour, B. and Woolgar, S. (1979). Laboratory Life: The Construction of Scientific Facts. Pinceton University Press, Princeton.

Law, J. (1992). Notes on the Theory of the Actor-Network: Ordering, Strategy and Heterogeneity. Systems Practice, 5, 379-93.

Law, J. (2004). After Method: Mess in Social Science Research, Routledge, London.

Lenz Taguchi, H. (2012). A diffractive and Deleuzian approach to analysing interview data. Feminist Theory. Vol 13(3), 265-281. https://doi.org/10.1177/1464700112456001

Lenz Taguchi, H. (2013a). Images of Thinking in Feminist Materialisms: Ontological divergences and the production of researcher subjectivities. International Journal of Qualitative Studies in Education. 26(6), 706-716. https://doi.org/10.1080/09518398.2013.788759

Lenz Taguchi, H. (2013b). 'Becoming molecular girl': transforming subjectivities in collaborative doctoral research studies as micro-politics in the academy. International Journal of Qualitative Studies in Education. 26 (9), 1101-1116. https://doi.org/10.1080/09518398.2013.816886

Mazzei, L. (2013). A voice without organs: interviewing in posthumanist research. International Journal of Qualitative Studies in Education. 26 (6), 732-740. https://doi.org/10.1080/09518398.2013.788761

Michael, M. (2004). On Making Data Social: Heterogeneity in Sociological Practice. Qualitative Research 4, 5-23. https://doi.org/10.1177/1468794104041105

Moats, D. (2016). Of stories and numbers: rethinking the settlement between Anthropology and metrics in Global Health. Science as culture. 25(4), 495-499. https://doi.org/10.1080/09505431.2016.1222362

Moberg, E. (2017a). Exploring the relational efforts making up a curriculum concept - an ANT analysis of the concept of children's interests. Journal of Curriculum Studies. https://doi.org/10.1080/00220272.2017.1320428

Moberg, E. (2017b). Children, sub-headings and verbal discussions creating evaluations: acknowledging the productiveness of ambivalence, Pedagogy, Culture and Society. https://doi.org/10.1080/14681366.2017.1403951

Moberg, E. (2017c). Breakdowns, overlaps and ambivalence: an Actor-network theory study of the Swedish preschool curriculum. Phd Diss. Stockholm University.

Mol, A. (2002). The Body Multiple: Ontology in Medical Practice. 3rd ed. Durham and Duke University Press, London. https://doi.org/10.1215/9780822384151

Mol, A. (2010). Actor-network theory: sensitive terms and enduring tensions. Kölner Zeitshrift fur Soziologie und Sozialpsychologie, 50 (1), 253-269.

Mulcahy, D. (2010). Assembling the accomplished teacher: The performativity and politics of professional teaching standards. Educational Philosophy and Theory, 43(1): 94-113.

Osgood, J. \& Guigni, M. (2015). Reconfiguring Quality: Beyond discourses and subjectivities to matter, bodies and becomings in early childhood education. In G.S. Cannella, G.S., Salazar Perez, M. 
\& Lee, I.(eds.) Critical Examinations of Quality in Childhood Education and Care: Regulation, Disequalification, and Erasure, 1-15. Peter Lang., Publisher: Peter Lang.

Sayes, E. (2014) Actor-Network Theory and methodology: Just what does it mean to say that nonhumans have agency? Social studies of science. 44 (1), 134-149. https://doi.org/10.1177/0306312713511867

Serder, M. (2015). Möten med Pisa. Kunskapsmätning som samspel mellan elever och provuppgifter $i$ och om naturvetenskap., Phd. Diss, Malmö Studies in Education, No 75.

St. Pierre, E. (2011) Refusing human being in humanist qualitative inquiry. In Denzin, N. and Giardina, M. D. (eds.) Sage handbook of qualitative inquiry, 611-635. Sage, Los Angeles.

Vallberg Roth, A-C. (2014). Bedömning i förskolans dokumentationspraktiker: fenomen, begrepp och reglering. Pedagogisk forskning i Sverige, 4-5, 403-437.

Vallberg Roth, A-C \& Månsson, A (2011). Individual development plans from a critical Didactic perspective: focusing on Montessori- and Reggio Emilia-profiled preschools in Sweden. Journal of Early Childhood Research, 3, 247-261. https://doi.org/10.1177/1476718X10389148

Verran, H. (1999). Staying true to the laughter in Nigerian classrooms. The Sociological Review, 47(1), 136-155. https://doi.org/10.1111/i.1467-954X.1999.tb03486.x

Woolgar, S. (1988). Reflexivity is the ethnographer of the text. In Woolgar, S. (eds.) Knowledge and Reflexivity: New Frontiers in the Sociology of Knowledge,1-11, Sage Publications, London. 